\title{
B chromosomes in Astyanax scabripinnis (Pisces, Characidae)
}

\author{
LARA BELLINTANI SALVADOR \& ORLANDO MOREIRA-FILHO \\ Universidade Federal de São Carlos, Departmento de Genética e Evolução, Caixa Postal 676, 13560 São Carlos, SP, \\ Brasil
}

\begin{abstract}
A karyotypic analysis was carried out using conventional staining and C-banding in 32 specimens of Astyanax scabripinnis (Pisces, Characidae) from Campos do Jordão (São Paulo State, Brazil). Twenty-eight individuals (87.5 per cent of the sample studied) showed 1-2 extra B-chromosomes, similar in size and shape (metacentrics) to pair 1 of the karyotype, with a high intra-individual constancy. Two types of $\mathrm{B}$ could be identified on the basis of their constitutive heterochromatin patterns. The hypothesis of the origin of the B-chromosome from non-disjunction of chromosome 1 , followed by a heterochromatinization process, is postulated.
\end{abstract}

Keywords: Astyanax scabripinnis, B-chromosomes, C-banding, karyotype.

\section{Introduction}

The growing number of papers on fish cytogenetics published over the last 20 years have significantly contributed to our knowledge of the karyotype structure of many fish species. Among the many discoveries reported are cases of accessory or B chromosomes. Accessory chromosomes were probably mentioned by Taylor (1967) in a study of Eptatretus stoutii. Pauls \& Bertollo (1983) reported the first detection of a B chromosome among Ostariophysi, in Prochilodus scrofa. Since this report, other cases have been detected in 18 species belonging to seven different families of bony fish (Table 1). Some of these cases can be characterized as B chromosomes, whereas others are reports of more sporadic occurrences of extra chromosomes. Karyotype studies conducted on Astyanax scabripinnis have demonstrated chromosome diversity in this species, with the detection of diploid numbers equal to 46,48 and 50 in different populations (Moreira-Filho et al., 1978; Morelli et al., 1983; Martins et al., 1984; Moreira-Filho \& Bertollo, 1986; Rocon-Stange \& Passamani, 1988; Maistro et al., 1990; Salvador \& Moreira-Filho, 1990).

Moreira-Filho \& Bertollo (1991) conducted karyotypic and morphological studies on seven populations of A. scabripinnis. Some populations were distinguishable by morphological traits, others by karyotypic traits, and still others by both types of characteristics. Six of the seven populations studied presented unique of exclusive traits at the morphological and/or chromo- some level which permitted their distinction and were therefore proposed to be distinct species.

This species complex is restricted to the headwaters of small tributaries. Thus, its diversity should be initially interpreted as a function of each microbasin in particular and later analysed in a comparative manner between larger draining systems (Moreira-Filho \& Bertollo, 1991).

\section{Materials and methods}

Thirty-two specimens ( 22 females and 10 males) of $A s$ tyanax scabripinnis (Fig. 1) were collected from the 'Córrego das Pedras' stream, municipality of Campos do Jordão, State of São Paulo, Brazil. This region presents a considerably irregular relief with altitudes ranging from 1800 to $730 \mathrm{~m}$, the collection site being located at $1720 \mathrm{~m}$.

Mitotic cells were obtained by the technique of Egozcue (1971), adapted by Bertollo (1978), and C banding was obtained by the method of Sumner (1972).

The chromosomes were measured with the aid of a dry-tip compass and pachymeter. The length of their short and long arms and the total length were obtained. The mean values were then calculated for each chromosome pair. The relative length (per cent) of the different pairs was calculated from these values in relation to the total length of the haploid lot. B chromosomes were included in the calculation. 
Table 1 Supernumerary chromosomes in Osteichthyes fish

\begin{tabular}{|c|c|c|c|c|c|c|c|}
\hline Family species & $\begin{array}{l}\text { Individual } \\
\text { analysis }\end{array}$ & $\begin{array}{l}\text { Individuals } \\
\text { with extra } \\
\text { chromosomes }\end{array}$ & $2 n$ & $\begin{array}{l}\text { Number of } \\
\text { extra } \\
\text { chromosomes }\end{array}$ & Size & Type & Reference \\
\hline \multicolumn{8}{|l|}{ Prochilodontidae } \\
\hline Prochilodus scrofa & 62 & 61 & 54 & $0-5$ & Micro & - & 1 \\
\hline P. scrofa & & & 54 & $0-7$ & Small & $\mathbf{M}$ & 2 \\
\hline P. cearenis & 7 & 5 & 54 & $0-2$ & Micro & - & 1 \\
\hline \multicolumn{8}{|l|}{ Curimatidae } \\
\hline $\begin{array}{l}\text { Cyphocharax modesta } \\
\text { cit. Curimata modesta }\end{array}$ & 10 & $1 \cdot$ & $3 x=81$ & 1 & Small & - & 3 \\
\hline Cyphocharax modesta & 17 & 1 & 54 & 1 & Micro & - & 4 \\
\hline \multicolumn{8}{|l|}{ Parodontidae } \\
\hline Apareiodon piracicabae & 20 & 1 & 54 & $0-1$ & Large & M & 5 \\
\hline \multicolumn{8}{|l|}{ Characidae } \\
\hline $\begin{array}{l}\text { Oligosarcus pintoi cit. } \\
\text { Paroligosarcus pintoi }\end{array}$ & 19 & 2 & 50 & $0-1$ & Large & $\mathbf{M}$ & 5 \\
\hline Moenkhausia intermedia & 14 & 8 & 50 & $0-1$ & Small & - & 6 \\
\hline M. sanctafilomenae & 30 & 30 & 50 & $1-8$ & Micro & - & 7 \\
\hline Astyanax eigenmanniorum & 3 & 1 & 50 & $0-1$ & Large & $\mathbf{M}$ & 8 \\
\hline A. scabripinnis & 29 & 3 & 50 & $0-2$ & Small & - & 9 \\
\hline A. scabripinnis & 15 & 1 & 50 & $0-1$ & Large & $\mathbf{M}$ & 10 \\
\hline A. scabripinnis & 32 & 28 & 50 & $0-2$ & Large & M & 11 \\
\hline Characidium cf $z e b r a$ & 28 & 1 & 50 & $0-1$ & Small & A & 12 \\
\hline Piabina argentea & 12 & 1 & 52 & $0-1$ & Small & - & 13 \\
\hline \multicolumn{8}{|l|}{ Pimelodidae } \\
\hline Pimelodella kronei & 5 & 1 & 50 & $0-1$ & Micro & - & 14 \\
\hline Bergiaria westermani & 7 & 7 & 56 & $0-5$ & Small & - & 15 \\
\hline Rhadia quelen & 30 & 13 & 58 & $0-2$ & Small & - & 16 \\
\hline R. hilarii & 51 & 50 & 58 & $0-5$ & Small & - & 17 \\
\hline \multicolumn{8}{|l|}{ Callichthyidae } \\
\hline Corydoras aeneus & 33 & 9 & 60 & $0-3$ & Small & - & 18 \\
\hline Callichthys callichthys & 27 & 18 & 58 & $0-16$ & Middle & $\mathrm{M} / \mathrm{SM}$ & 19 \\
\hline \multicolumn{8}{|l|}{ Loricariidae } \\
\hline $\begin{array}{l}\text { Microlepidogaster } \\
\text { M. leucofrenatus }\end{array}$ & 34 & 9 & 54 & $0-2$ & Large & $\mathbf{M}$ & 20 \\
\hline \multicolumn{8}{|l|}{ Cichlidae } \\
\hline Gymnogeophagus balzanii & 4 & 3 & 48 & $0-4$ & Micro & - & 21 \\
\hline
\end{tabular}

\section{References:}

1. Pauls \& Bertollo (1990)

2. Cavallaro \& Bertollo (1990)

3. Venere \& Galetti Jr (1985)

4. Venere (1991)

5. Falcão et al. (1984)

6. Portela et al. (1988)

7. Foresti et al. (1989)

8. Stripeck et al. (1985)

9. Rocon-Stange \& Passamani (1988)

10. Maistro et al. $(1990)$
11. Present paper

12. Miyazawa (1991)

13. Wasko, (1991)

14. Almeida Toledo et al. (1985)

15. Dias (1987)

16. Hochberg \& Erdtmann (1988)

17. Fenocchio \& Bertollo (1990)

18. Oliveira et al. (1986)

19. Erdtmann et al. (1990)

20. Andreata (1991)

21. Feldberg \& Bertollo (1984)
$\mathbf{M}=$ metacentric

$\mathrm{A}=$ acrocentric

$\mathrm{M} / \mathrm{SM}=$ metacentric or submetacentric 


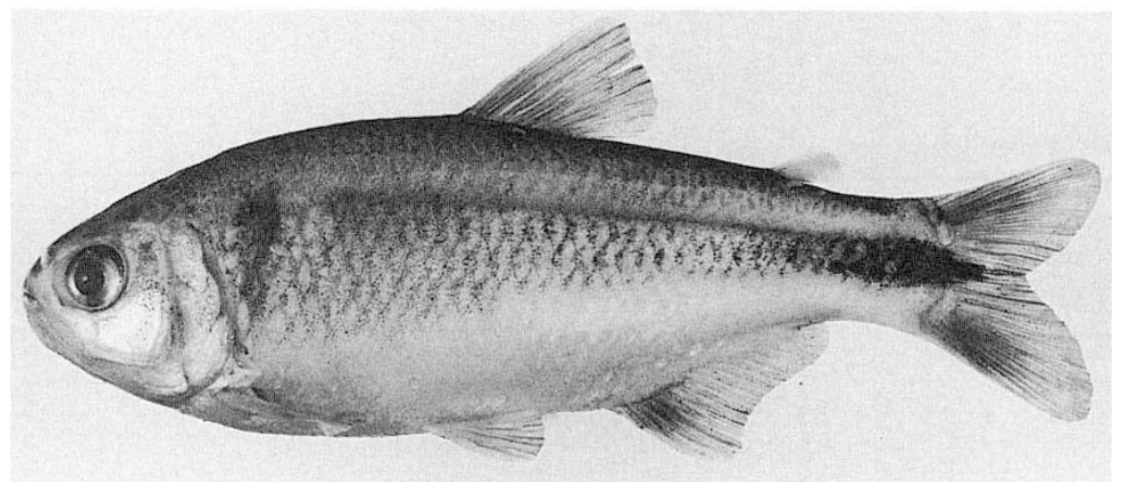

Fig. 1 Astyanax scabripinnis specimen from the 'Córrego das Pedras' stream, Campos do Jordão, SP, Brazil.

Standard length $=8.0 \mathrm{~cm}$.
The chromosomes were identified using the arm ratio (AR) criteria proposed by Levan et al. (1964) and classified as metacentrics $(\mathrm{M}: \mathrm{AR}=1.00-1.70)$, submetacentrics (SM: $\quad A R=1.71-3.00)$, subtelocentrics ( $\mathrm{ST}: \mathrm{AR}=3.01-7.00$ ), and acrocentrics (A: $\mathrm{AR}>7.01$ ).

\section{Results}

A total of 502 metaphase preparations from males and females were analysed, and 367 cells were found to have 50 chromosomes, corresponding to 73.1 per cent of the total number examined. Thus, the diploid number of $A$. scabripinnis from the Campos do Jordão site is $2 n=50$. Chromosome measurements and classification showed that the basic karyotype consists of three pairs of metacentric chromosomes, 11 pairs of submetacentrics, five pairs of subtelocentrics, and six pairs of acrocentrics, with a fundamental number (FN) equal to 88 (Table 2 and Fig. 2).

Extra chromosomes were detected in 28 of the 32 specimens investigated, with 19 females and eight males presenting only one of this kind of chromosome in 100 per cent of their metaphases (Table 3). This chromosome is of the metacentric type, large in size and slightly smaller than the first pair in the basic karyotype complement (Fig. 3). Two accessory chromosomes of similar morphology and size (Fig. 4) were detected in 100 per cent of complete metaphases obtained from one female (Table 3 ). In the remaining individuals, two females and two males, no extra chromosome was detected in any of the cells examined.

C-banding permitted the characterization of at least two types of supernumerary chromosomes in terms of the heterochromatin pattern. One of them was fully heterochromatic and the other presented a median euchromatin segment on each side of the centromere, with distal heterochromatin blocks (Fig. 5). One or the other of these chromosome types was observed in the specimens with a single supernumerary chromosome. Both chromosome types were present in the individual with two extra chromosomes (Fig. 5).
Table 2 Chromosome measurements and types in Astyanax scabripinnis from Campos do Jordão, SP, Brazil

\begin{tabular}{|c|c|c|c|c|c|c|}
\hline \multirow[b]{2}{*}{ Pair } & \multicolumn{6}{|c|}{ Pair means } \\
\hline & $p$ & $q$ & $T L$ & $R L(\%)$ & $A R$ & Type \\
\hline 1 & 11.67 & 15.67 & 27.34 & 8.17 & 1.34 & $\mathbf{M}$ \\
\hline 2 & 5.92 & 7.42 & 13.34 & 3.99 & 1.25 & $\mathrm{M}$ \\
\hline 3 & 5.15 & 7.32 & 12.47 & 3.73 & 1.42 & $\mathrm{M}$ \\
\hline 4 & 6.02 & 10.95 & 16.97 & 5.07 & 1.82 & SM \\
\hline 5 & 3.65 & 8.15 & 11.80 & 3.53 & 2.23 & SM \\
\hline 6 & 3.70 & 8.07 & 11.77 & 3.52 & 2.18 & SM \\
\hline 7 & 3.25 & 7.95 & 11.20 & 3.35 & 2.44 & SM \\
\hline 8 & 3.20 & 7.95 & 11.15 & 3.33 & 2.45 & SM \\
\hline 9 & 3.30 & 7.50 & 10.80 & 3.23 & 2.27 & SM \\
\hline 10 & 3.40 & 7.22 & 10.62 & 3.17 & 2.12 & SM \\
\hline 11 & 2.70 & 7.07 & 9.77 & 2.92 & 2.62 & SM \\
\hline 12 & 2.69 & 7.07 & 9.76 & 2.92 & 2.62 & $\mathrm{SM}$ \\
\hline 13 & 3.00 & 5.30 & 8.30 & 2.48 & 1.76 & $\mathrm{SM}$ \\
\hline 14 & 2.57 & 5.41 & 7.98 & 2.39 & 2.10 & SM \\
\hline 15 & 1.97 & 8.40 & 10.37 & 3.10 & 4.26 & ST \\
\hline 16 & 2.57 & 7.75 & 10.32 & 3.08 & 3.01 & ST \\
\hline 17 & 1.60 & 8.50 & 10.10 & 3.02 & 5.31 & $\mathrm{ST}$ \\
\hline 18 & 2.10 & 7.45 & 9.55 & 2.85 & 3.54 & ST \\
\hline 19 & 2.37 & 7.15 & 9.52 & 2.85 & 3.01 & ST \\
\hline 20 & 1.25 & 12.22 & 13.47 & 4.02 & 9.77 & A \\
\hline 21 & 0.75 & 12.45 & 13.20 & 3.94 & 16.60 & A \\
\hline 22 & 1.10 & 10.35 & 11.45 & 3.42 & 9.41 & A \\
\hline 23 & 0.80 & 10.52 & 11.32 & 3.38 & 13.15 & A \\
\hline 24 & 1.20 & 9.05 & 10.25 & 3.06 & 7.54 & A \\
\hline 25 & 0.50 & 7.45 & 7.95 & 2.38 & 14.90 & A \\
\hline $\mathrm{B}^{1}$ & 10.45 & 11.85 & 22.30 & 6.67 & 1.13 & $\mathrm{M}$ \\
\hline $\mathrm{B}^{2}$ & 9.65 & 11.85 & 21.50 & 6.43 & 1.22 & $\mathbf{M}$ \\
\hline
\end{tabular}

$p=$ short arm.

$q=$ long arm.

$\mathrm{M}=$ metacentric

$T L=$ total length.

$\mathrm{SM}=$ Submetacentric

$R L(\%)=$ relative length.

$\mathrm{ST}=$ Subtelocentric

$A=$ acrocentric

$\mathrm{B}^{1}=\mathrm{B}$ chromosome type 1

$\mathrm{B}^{2}=\mathrm{B}$ chromosome type 2

The first supernumeracy chromosome type had 6.67 per cent participation in the relative length of the haploid lot, and the second, 6.43 per cent. Thus, the two chromosomes types taken together represented 13 
Fig. 2 Basic karyotype of an Astyanax scabripinnis male from Campos do Jordão, SP, Brazil.

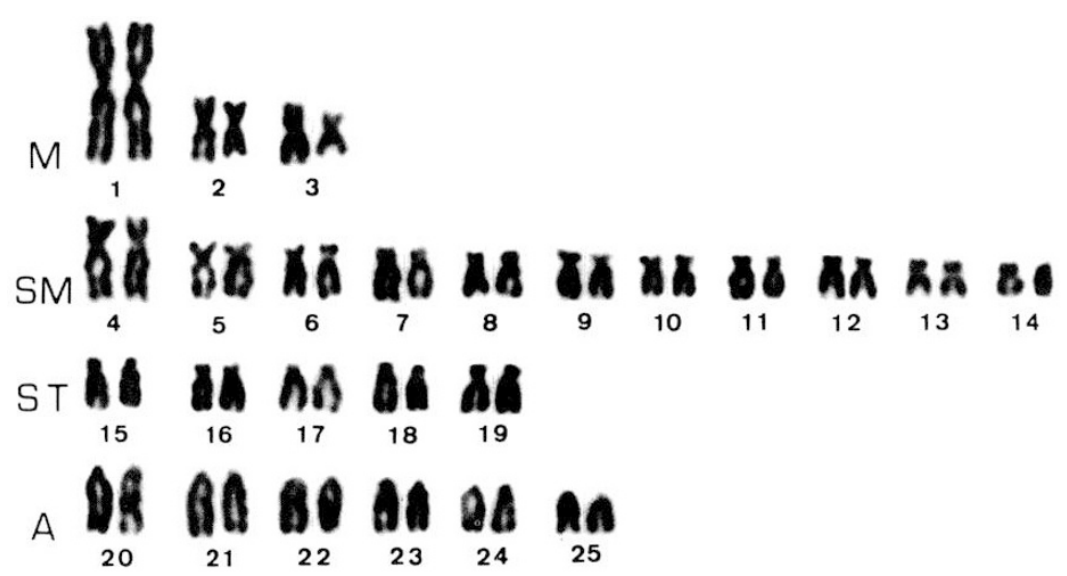

Table 3 Frequency of $\mathrm{B}$ chromosome per cell in females and males of A. scabripinnis from Campos do Jordão, SP, Brazil

\begin{tabular}{|c|c|c|c|c|c|c|}
\hline \multirow[b]{2}{*}{ Fish } & \multicolumn{3}{|c|}{$\begin{array}{l}\text { Number of B } \\
\text { chromosomes/cell }\end{array}$} & \multirow[b]{2}{*}{ Number of B } & \multirow{2}{*}{$\begin{array}{l}\text { Number of cells } \\
\text { analysed }\end{array}$} & \multirow[b]{2}{*}{ Cells with $\mathrm{B}(\%)$} \\
\hline & 0 & 1 & 2 & & & \\
\hline $6164 \%$ & 23 & - & - & 0 & 23 & 0 \\
\hline 61669 & - & 31 & - & 1 & 31 & 100 \\
\hline $6167 \%$ & - & 16 & - & 1 & 16 & 100 \\
\hline $6168 \%$ & 17 & - & - & 0 & 17 & 0 \\
\hline $6176 \%$ & - & 02 & - & 1 & 02 & 100 \\
\hline $6911 \%$ & - & 08 & - & 1 & 08 & 100 \\
\hline $6912 \%$ & - & 05 & - & 1 & 05 & 100 \\
\hline $6916 \%$ & - & 12 & - & 1 & 12 & 100 \\
\hline $6917 \%$ & - & 05 & - & 1 & 05 & 100 \\
\hline $6944 \%$ & - & 17 & - & 1 & 17 & 100 \\
\hline $6956 \%$ & - & 14 & - & 1 & 14 & 100 \\
\hline $6977 \%$ & - & 06 & - & 1 & 06 & 100 \\
\hline 6979 q & - & 20 & - & 1 & 20 & 100 \\
\hline $6985 \%$ & - & 06 & - & 1 & 06 & 100 \\
\hline $6986 \%$ & - & 02 & - & 1 & 02 & 100 \\
\hline $6987 \%$ & - & 04 & - & 1 & 04 & 100 \\
\hline $6988 \%$ & - & 07 & - & 1 & 07 & 100 \\
\hline $6989 \%$ & - & 09 & - & 1 & 09 & 100 \\
\hline $6990 \%$ & - & - & 20 & 2 & 20 & 100 \\
\hline $6991 \%$ & - & 24 & - & 1 & 24 & 100 \\
\hline $7550 \%$ & - & 09 & - & 1 & 09 & 100 \\
\hline $7581 \%$ & - & 07 & - & 1 & 07 & 100 \\
\hline $61690^{\circ}$ & - & 15 & - & 1 & 15 & 100 \\
\hline $61750^{\circ}$ & - & 15 & - & 1 & 15 & 100 \\
\hline 69190 & - & 06 & - & 1 & 06 & 100 \\
\hline 69430 & 22 & - & - & 0 & 22 & 0 \\
\hline 69450 & - & 08 & - & 1 & 08 & 100 \\
\hline $69720^{\circ}$ & - & 06 & - & 1 & 06 & 100 \\
\hline 6973 o & - & 04 & - & 1 & 04 & 100 \\
\hline 69800 & - & 05 & - & 1 & 05 & 100 \\
\hline 69810 & - & 02 & - & 1 & 12 & 100 \\
\hline 71070 & 20 & - & - & 0 & 20 & 0 \\
\hline \multicolumn{5}{|c|}{ Total number of cells analysed } & 367 & \\
\hline
\end{tabular}



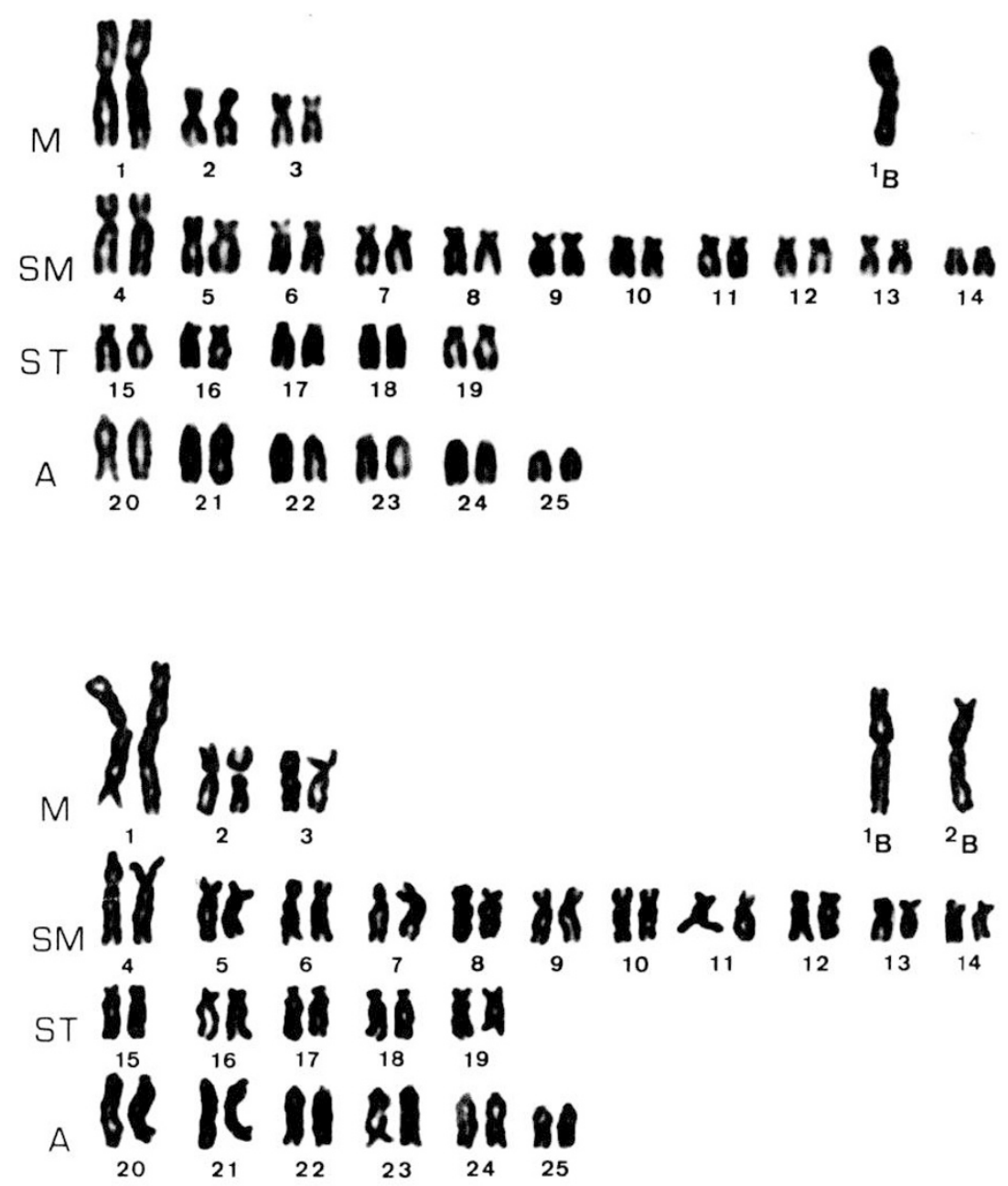

Fig. 3 Karyotype of an Astyanax scabripinnis male from Campos do Jordão, SP, Brazil, showing a B chromosome.
Fig. 4 Karyotype of an Astyanax scabripinnis female from Campos do Jordão, SP, Brazil, showing two B chromosomes. per cent of the haploid complement of the species (Table 2).

\section{Discussion}

A. scabripinnis from Campos do Jordão (SP) presents a diploid number equal to 50 chromosomes and its karyotype complement is similar to those detected by Moreira-Filho and Bertollo (1992) in two populations from different sites (Salesópolis and São Carlos: State of São Paulo, Brazil) but differs in the number of ST and A chromosomes. This difference may be due in part to the fact that several of these chromosomes present an AR close to the classifying limit of these two chromosome classes. However, A. scabripinnis from Campos do Jordão shows the peculiarity of extra chromosome in its karyotype. The occurrence of these chromosomes at the population level, as well as their characteristics permit us to consider them to be $B$ chromosomes.
The constancy of these chromosomes in 100 per cent of the cells from the individuals bearing them (Table 3 ) indicates that some mechanism must exist to insure the stability of these chromosomes in the karyotype complement, although it has not yet been possible to conduct a study on the behaviour of these chromosomes during meiosis. On this basis, the $\mathrm{B}$ chromosomes of $A$. scabripinnis present interesting characteristics related not only to their high incidence in the population ( 87.5 per cent of the individuals analysed) but also to their intra-individual constancy.

Volobujev (1981) raised two hypotheses to explain the origin of B chromosomes. One proposes that B chromosomes may be relics of structural rearrangements that occurred during the evolution of the ancestral karyotype. The other proposes that these chromosomes may result from autosome or sex chromosome non-disjunction followed by a process of genetic inactivation. 
Fig. 5 Types of $\mathrm{B}$ chromosomes detected by C-banding in Astyanax scabripinnis from Campos do Jordão, SP, Brazil. (a) Metaphase showing a fully heterochromatic B chromosome (arrow).(b) Metaphase with a partially euchromatic B chromosome in the middle region (arrow). (c) Metaphase with two B types present (arrows). The inset at lower right gives details of the two B types observed.

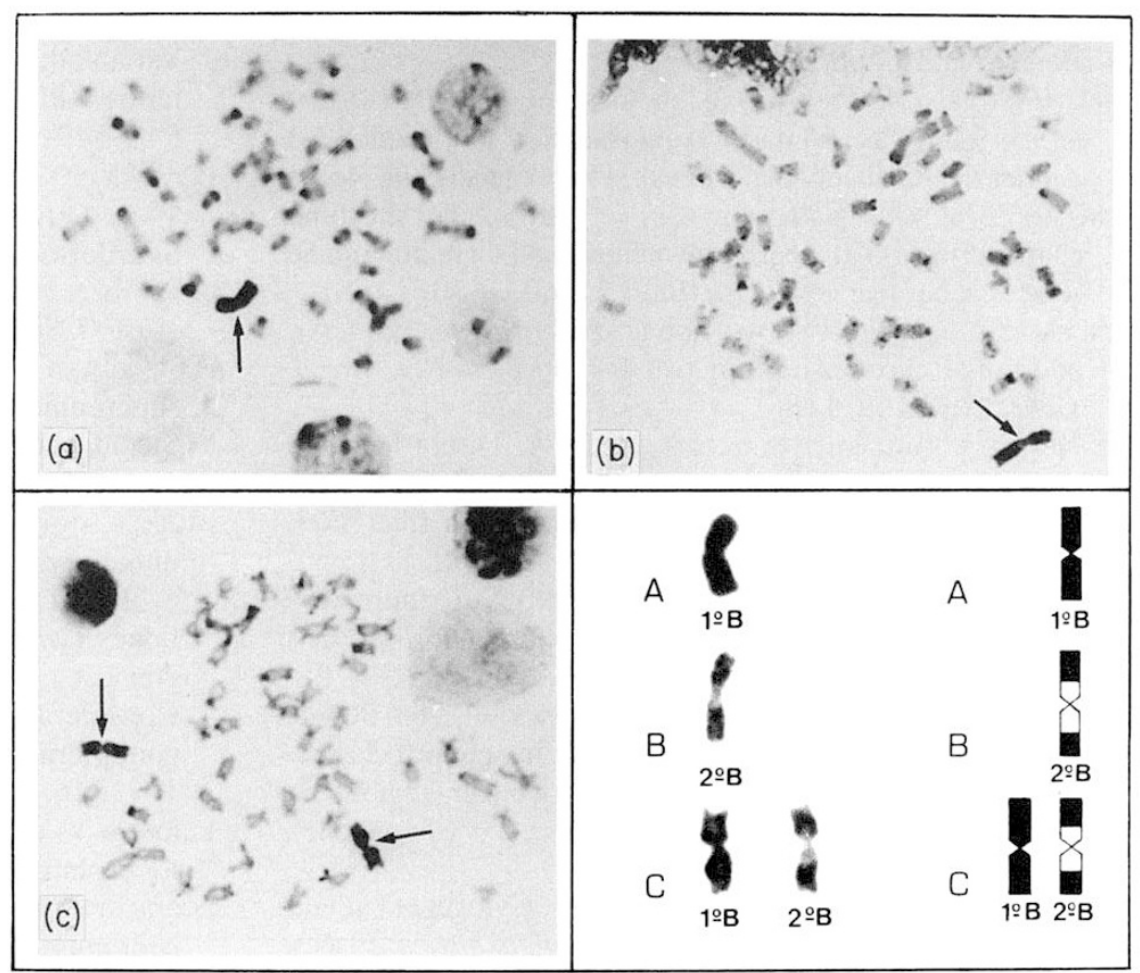

Scheel (1973) and later Morelli et al. (1983) and Falcão \& Bertollo (1985) have emphasized as a widely diffuse characteristic of Characidae the presence of a first metacentric chromosome pair which is higher than the remaining chromosomes in the karyotype complement. This chromosome pair is also present in the basic karyotype of $A$. scabripinnis from Campos do Jordão. In turn, the $\mathrm{B}$ chromosomes detected in this population are similar in both size and shape to the first pair in the complement. On this basis, it may be suggested that they probably originated from nondisjunction of one of these chromosomes followed by heterochromatinization, in agreement with the second hypothesis raised by Volobujev (1981).

According to Rejon et al. (1987), the heterochromatinization of the B chromosome may be of a selective evolutionary nature because this chromosome may have harmful effects on the organism which would be minimized by a process of heterochromatinization. The heterochromatin patterns presented by the $\mathrm{B}$ chromosomes of $A$. scabripinnis from Campos do Jordão (Fig. 5) may represent distinct stages of heterochromatinization and consequently of genetic inactivation of these chromosomes. The high incidence of $\mathrm{B}$ in the population analysed may be justified by the specific characteristics of the scabripinnis group, which forms small isolated populations and reproduces at different times of the year, a fact that would favour an easier fixation of these chromosomes in the population.

\section{Acknowledgements}

The authors are grateful to Dr Heraldo Britski for taxonomic identification. Funds to support this study were provided by FAPESP and CNPq.

\section{References}

ALMEIDA-TOLEDO, L. F., TRAJANO, E., TOLEDO-FILHO, S. A. AND FORESTI, F. 1985. Análise citogenética comparativa entre peixe cego Pimelodella kronei, das grutas de Iporanga (SP) e seu possivel ancestral. Pimelodella transitoria. Abstr. Cienc. Cult., 37, 777.

ANDreatA, A. A. 1991. Estudos Citogenéticos no Subfamilia Hypopoptopomatinae (Pisces siluriformes, horicariidae) Master's Thesis. Departamento de Biologia, Instituto de Biociências da Universidade de São Paulo, Brazil.

Bertollo, L. A. C. 1978. Estudos Citogenéticos no Gênero Hoplias Gill, 1903 (Pisces, Ergthrinidae) Ph. D. Thesis. Faculdade de Medicina de Ribeirão Preto, Universidade de São Paulo, Brazil.

CAVAllaro, Z. I. AND Bertollo, L. A. c. 1990. Estudo comparativo dos cromossomos B de Prochilodus scrofa (Teleostei, Characiformes, Prochilodontidade) do rio Mogi-Guaçu e de amostras cultivadas. Abstr. III Simp. Citogen. Evolut. Aplic. Peixes Neotrop., 22.

DIAS, A. L. 1987. Análises Citogenéticas de Peixes da Familia Pimelodidae (Pisces-Siluriformes) Master's Thesis. Departamento de Ciências Biológicas. Universidade Federal de São Carlos, Brazil. 
Egozcue, J. 1971. Técnicas em Citogenética. Editorial Espaxs, Barcelona, 144 pp.

ERDTMANN, B., CALACAGNOTO, D., RABOLINI, L. AND MALABARBA, L. R. 1990. Variabilidade cromossômica em Callichthys callichthys (Callichtydae, Pisces). Abstr. Cienc. Cult., 452.

FALCẢO, J. N. AND BERTOLLO, L. A. C. 1985. Chromosome characterization in Acestrorhynchinae and Cynopotaminae (Pisces, Characidae). J. Fish. Biol., 27, 603-610.

FALCAO, J. N., MOREIRA-FILHO, O. AND BERTOLLO, L. A. C. 1984. An additional chromosome in two fish species. Rev. Brasil. Genet., 7, 1, 109-118.

FELDBERG, E. AND BERTOLLo, L. A. C. 1984. Discordance in chromosome number among somatic and gonadal tissue cells of Gymnogeophagus balzanii (Pisces, Cichlidae). Rev. Brasil, Genet., 4, 639-645.

FENOCCHIO, A. S. AND BERTOLLO, L. A. C. 1990. Supernumerary chromosome in a Rhamdia hilarii population (Pisces, Pimelodidae). Genetica, 81, 193-198.

FORESTI, F., ALMEIDA-TOLEDO, L. F. AND TOLEDO, S. A. 1989. Supernumerary chromosome system, C-banding pattern characterization and multiple nucleolus organizer regions in Meonkhausia sanctafilomenae (Pisces, Characidae). Genetica, 79, 107-114.

HOCHBERG, v. B. M. AND ERDTMANN, B. 1988. Cytogenetical and morphological considerations on Rhamdia quelen (Pisces, Pimelodidae) - the occurrence of B chromosomes and polymorphic NOR regions. Rev. Brasil. Genet., 11, 563-576.

LEVAN, A., FREDGA, K. AND SANDBERG, A. A. 1964. Nomenclature for centromeric position on chromosomes. Hereditas, $\mathbf{5 2}$, 201-220.

MAISTRO, L. M., FORESTI, F. AND OLIVEIRA, C. 1990. Ocorrência de macrocromossomo extranumerário em Astyanax scabripinnis (Pisces, Characidae). Abstr. III Simp. Citogenet. Evolut. Aplic. Peixes Neotrop., 15.

MARTINS, N. S., OLIVEIRA, M. A., WALDRIGUES, A., GIULIANO, L. AND ARAújo, A. M. L. V. 1984. Estudo cariotípico de Astyanax scabripinnis paranae da região de Londrina, PR. Abstr. Ciên. Cult., 36, 862-863.

miYazaWA, C. A. 1991. Estudo Cariotipico Comparativa de Espécies e Populacoes Distintas do Gênero Characidium (Characidiinae, Characidae). Considircicoes Citotaxonomicas e Evolutivas. Master's Thesis. Departamento de Ciências Biológicas, Universidade Federal de São Carlos, Brazil.

MORELLI, S., BERTOLLO, L. A. C., FORESTI, F., MOREIRA-FILHO, O. AND TOLEDo, F. S. A. 1983. Cytogenetic considerations on genus Astyanax (Pisces, Characidae). I. Karyotypic variability. Caryologia, 36, 235-244.

MOREIRA-FILHO, O. AND BERTOLLO, L. A. C. 1986. Estudo cariotípico comparativo nos grupos fasciatus e scabripinnis (Teleostei, Characiformes, Characidae). Abstr. I. Simp. Citogenet. Evolut. Aplic. de Peixes Neotrop., 50.

MOREIRA-FILHO, O. AND BERTOLLO, L. A. C. 1991. Astyanax scabripinnis (Pisces, Characidae) a species complex. Rev. Brasil. Genet., 142, 331-357.
MOREIRA-FILHO, O., GALETTI Jr., P. M. AND BERTOLLO, L. A. C. 1978. Variabilidade cromossômica na subfamília Tetragonopterine (Pisces, Characidae). Abstr. Ciênc. Cult., 30, 548-549.

OliVEIRA, C. de, ALMEIDA-TOLEDO, L. F. AND TOLEDO-FILHo, S. A. 1986. Estudos citogenéticos no gênero Corydoras (Pisces, Siluriformes, Callichthydae). III. Estudos preliminares sobre o conteúdo de DNA de $C$. aeneus $C$. schwartzi. Abstr. I. Simp. Citogenet. Evol. Aplic. Peixes Neotrop., 52.

PAULS, E. AND BERTOLLO, L. A. C. 1983. Evidence for a system of supernumerary chromosomes in Prochilodus scrofa Steindachner, 1881 (Pisces, Prochilodontidae). Caryologia, 36, 307-314.

PAULS, E. AND BERTOLLO, L. A. C. 1990. Distribution of a supernumerary chromosome system and aspects of karyotypic evolution in the genus Prochilodus (Pisces, Prochilodontidae). Genética, 81, 117-123.

PORTELA, A. L. B. S., GALETTI, Jr., P. M. AND BERTOLLo, L. A. C. 1988. Considerations on the chromosome evolution of Tetragonopterinae (Pisces, Characidae). Rev. Brasil. Genet., 11, 307-316.

REJON, M. R., REJON, C. R. AND OLIVER, J. L. 1987. Evolución de los cromosomas B. Investigación y Ciéncia, 133, 92-101.

RoCON-STANGE, E. A. AND PASSAMANI, M. 1988. Cromossomos supranumerários e regiões organizadoras nucleolares múltiplas em Astyanax scabripinnis (Characidae). Abstr. XV. Congr. Brasil. Zool., 383.

SALVADOR, L. B. AND MOREIRA-FILHO, o. 1990. Ocorrência de cromossomos B em Astyanax scabripinnis, encontrados em altitude elevada. Abstr. III Simp. Citogenet. Evolut. Aplic. Peixes Neotrop., 14.

SCHEEL, J. J. 1973. Fish chromosomes and their evolution. Internal Report of Danmarks Akvarium, Charlottenlund, Denmarks, 22.

STANGE, E. A. R., SILVA, v. E. AND DUTRA, S. A. 1986. Citogenética no gênero Astyanax (Pisces, Characidae) das bacias dos rios Benevente e Jucu. Abstr. I Simp. Citogenet. Evolut. Aplic. Peixes Neotrop., 58.

STRIPECKE, R., NOGUEIRA PINTO, M. T., HACKEL, C. AND SAZIMA, I. 1985. O cariótipo de Astyanax eigemannionum (Osteichthyes, Characidae). Abstr. XII Cong. Brasil. Zool., 173-174.

SUMNER, A. T. 1972. A simple technique for demonstrating centromeric heterochromatin. Exp. Cell. Res., 75, 304-306.

TAYLOR, K. M. 1967. The chromosomes in some lower chordatas. Chromosoma, 21, 181-188.

venere, P. C. 1991. Citogenética Comparativa de Peixes da Familia Curinatidae (Characiformes). Master Thesis. Departamento de Ciências Biológicas, Universidade Federal de São Carlos, Brazil.

VENERE, P. C. AND GALETTI, Jr., P. M. 1985. Natural triploid and chromosome $\mathrm{B}$ in the fish Curimata modesta (Curimatidae, Characiformes). Rev. Brasil. Genet., 4, 681-687.

volobujev, v. T. 1981. B-chromosome system of the mammals. Caryologia, 34, 1-23. 